\title{
The Pitfalls, Principles and Priorities of Establishing a New Global Economic Order
}

\author{
Pascal Lamy
}

\begin{abstract}
Some scholars call it the world legal economic order, while others describe it as the 'rules-based' global order. This essay contends that the world urgently needs a new economic order. While the world cannot, and should not, revolutionize the system that is currently in place, it does need to consider how it should be reorganized and subsequently replaced by a new order. It is essential that a new order serves not only the established world powers but a greater number of the newly emerging economies and nations. The development of this new order must ensure that it is representative of a world that is markedly different from the post Second World War 'legal economic order'. Those creating the new order are dealing with new challenges that could not even be imagined at the end of the Second World War. Humanity now inhabits a world that is more interconnected, more interdependent and, in a word, more 'global'. This connectivity is part and parcel of the process of globalization, which at this point cannot be avoided. China and other emerging powers will be greater contributors to the process of globalization if they follow fundamental principles that benefit all of mankind.
\end{abstract}

Keywords World legal economic order • 'Rules-based' global order • New economic order - Established world powers - Emerging economies and nations • Interconnected

\section{Genesis of the Current Global 'Economic Order'}

An 'economic order' or system is, in my view, the superstructure of an infrastructure of production systems, the purpose of which is to create value for people. It cannot be understood, nor established, without a deep comprehension of the economic infrastructure. In turn, it requires a grasp of the principles and structural framework of any economy. This is true for domestic economics as well as at the global level. In this essay, I will attempt to explain why, in my view, a new global economic order is needed.

P. Lamy $(\bowtie)$

Paris Peace Forum, Paris, France 
The current economic order is a legacy of Western capitalism that has developed since the sixteenth century following successive waves of globalization. The ideology underpinning this development is based on liberalism, markets and free enterprise, while science, technology and competition are seen as the main sources of innovation and economic growth.

This order has to be organized by a rules-based system, represented in the notion of 'ordoliberalism'. 'The theoretical foundation of this system was established by Adam Smith, David Ricardo and Joseph Schumpeter, who developed concepts such as the 'invisible hand', 'comparative advantage' and 'creative destruction'. This ultimately resulted in two different schools of thought stemming from this common trunk: Hayek's analysis of laissez-faire capitalism and Keynes' emphasis on the importance of the state in macroeconomic management.

These principles were then enshrined in treaties and multilateral institutions. The catalyst for the core gatherings that laid the foundations of this global 'legal economic order' was the Second World War. For example, the 1944 Bretton Woods System Conference and the 1948 Havana Charter Conference. These meetings led to the creation of the International Monetary Fund (IMF), the World Bank and the General Agreement on Tariffs and Trade (GATT). In turn, GATT evolved into the World Trade Organization (WTO) in 1994.

The purpose underpinning this system, later labelled as the 'Washington Consensus', ${ }^{2}$ was to promote private enterprise, open trade and investment, and ensure financial and monetary stability. This system successfully competed during the 'Cold War' with the so-called 'non-market economies' such as the state-run centrally planned communist economies like the Soviet Union. It was considered unrivalled after the fall of the Berlin Wall in 1989. As John Ruggie argued, it represented a system of 'embedded liberalism' - a global balance between openness and regulation, capital and labour, markets and society. ${ }^{3}$

This global economic order generally delivered steady economic growth, in both developed and developing countries, for a period of roughly 60 years following the end of the Second World War in 1945. However, it has run into trouble for the last 20 years. The problems came into sharp focus as an outcome of the 2008 global financial crisis. This system is now being questioned for several reasons. The foremost questions focus on financial instability, an increase in inequality; negative

\footnotetext{
${ }^{1}$ First developed around and during the Second World War, ordoliberalism grew out of the work of economists and legal theorists associated with the Freiburg School, such as Walter Eucken and Franz Böhm. At its core, the ordoliberal tradition converges around the idea of an economic constitution. Recognizing the contingencies borne out of the free market, ordoliberals are committed to robust state intervention in the form of a concrete set of rules directing socio-economic activity.

${ }^{2}$ The term Washington Consensus usually refers to a level of agreement between the International Monetary Fund (IMF), World Bank and U.S. Department of the Treasury that the operation of the free market and the reduction of state involvement were crucial to economic development.

${ }^{3}$ In a widely cited 1982 article, John Ruggie identified the normative framework of the Bretton Woods System as 'embedded liberalism' and pointed to its enduring legacy in international economic governance through the 1970s.
} 
environmental externalities; a deficit in global governance and a geopolitical shift brought about by China's increasingly prominent status.

\section{Global Systemic Flaws in Finance, Trade and Inequality}

Financial instability, a well-known feature of capitalism, was one of the main factors that led to the 2008 world economic crisis. The root of the crisis was mainly due to insufficient regulation of a financial industry which had rapidly globalized.

The close links that had been established after the Second World War between economic development, trade and investment and monetary stability, were built on a foundation of fixed currency exchange rates. This principle was abandoned in 1973. The outcome was a movement that created excessive financial deregulation of many economies.

The sheer scale of the economic outcome and financial deregulation has been to embed great complexity into the system. Another serious outcome has been the creation of exotic financial instruments and where they are now packaged and repackaged into ever more complex products. This makes it increasingly hard to understand the international financial system, let alone regulate it.

Even more challenging is the need to match an increasingly open world trading system with greater international fiscal and monetary coordination. Global macroeconomic imbalances were a major cause of the recent financial crisis. But the macroeconomic adjustment, which conventional wisdom says is needed to reduce surpluses in Asia, and reduce deficits in America-has barely begun.

Meanwhile, the successive waves of globalization also promoted the growth of inequalities. While market-based capitalist globalization was efficient in reshuffling capital and labour in a more productive way, it was, as expected, painful for the losers. Even if, on a global scale, the benefits of efficiency outweighed the negative impact of the pain caused, local distribution of these benefits has become increasingly unbalanced, resulting in growing criticism over unfairness. This in turn led to people questioning the previous consensus, which stated that the playing field between developed and developing countries could only be levelled gradually in order to preserve necessary policy space for weaker economies.

\section{Globalization-The Future}

However, despite this negative side-effect, we should be careful to not dismiss globalization itself. Some think that COVID-19 spells the end of globalization and this may be true to some (limited, in my view) extent from the perspective of the US or Europe, but look at the rest of the world: Asia wants to resume the process as quickly as possible, and the same commitment comes for Africa. For most of the world, globalization is the way to get out of poverty and may entail for some time, an 
increase in inequality. I would caution that the globalization of fear is not the same as the fear of globalization.

\section{The Environment and COVID-19}

Another result of this rapid expansion of market capitalism was the rapid growth of negative environmental externalities, starting with carbon emissions, which have led to global warming. A consensus is slowly emerging that states the current 'economic order' model is not sustainable and has to be reformed, starting with the way growth is measured. The COVID-19 pandemic, which has resulted in enormous global damage, unprecedented since the Second World War, is likely to reinforce the trend towards preventing future environmental crises.

Geopolitically, COVID-19 has made the triangle of the EU, US and China even more fragmented and more difficult to manage. Bilateral relationships within this triangle have also been severely damaged by the COVID-19 crisis. That's the bad news. However, the good news is that, while Joe Biden does not have a magic wand, there is a good reason to believe that the US has come back to the table of international cooperation. That trend will be beneficial for moving things forward.

The most urgent and short-term matter for bringing COVID-19 under control is vaccines. We know that China, the US and the EU are covered regardless of which vaccine comes first and the citizens of those countries will be vaccinated. The real problem is what do we do with parts of the world that do not have effective access to a vaccine. This makes up roughly more than half of the world's population and is a major issue of international cooperation in times to come.

\section{The Deficit in Global Governance}

This challenge of international cooperation, and a number of other problems, stem from a fourth issue arising from the current 'economic order': a deficit in global governance.

Globalization produced a number of new common challenges, but arrangements between sovereign nation-states did not rise to these challenges. This was despite the existence of the very international fora meant to coordinate them such as the G7, which had its genesis in 1973, or the G20 that evolved with the financial crisis. The mediocre level of international cooperation during the COVID-19 crisis is a clear manifestation of this deficit.

The drive towards globalization has presented immense opportunities and huge economic and social benefits, but it has also resulted in concomitant inequalities, instability, contagion and stresses to humanity and the earth. This combination represents an issue for global governance in how to harness globalization in order to maximize its benefits and minimize its costs. It has become painfully clear that the 
current global governance system is insufficient to address borderless challenges like reducing carbon emissions, combating protectionism, currency volatility, tax evasion or cyber criminality. These and other problems can only be addressed with a new form of global governance.

The emergence of the current collection of international organizations has been an arduous and painful process. But it has emerged, underpinned by the treaties through which state entities have gradually agreed to renounce portions of their sovereignty. However, today, the pace at which global governance is being advanced by dominant players in the world has stalled to a near standstill due to a sequence of geotechnical, geoeconomic and geopolitical developments that have intensified existing obstacles.

The emergence of developing economies in the wake of globalization has also fundamentally reoriented the global balance of power between North and South, East and West. These emerging powers have leveraged market capitalism and information technologies to realize economic and social development at astonishing speeds.

\section{Unlocking The Global Governance Gridlock}

These complications and recent crises have caused international governance itself to also enter a sort of crisis phase, seemingly incapable of adapting to the new global balance or creating new common ground on which to cooperate. We currently find ourselves in a context of global governance gridlock.

However, despite these difficult circumstances, I believe that there are some avenues that could allow us to bridge the gap. In order to do so, it is important that we abandon the idea of a 'big bang' in global governance-the likes of which would only result from a major global conflict, which fortunately, I think we can avoid.

I believe the way forward to unlock the global governance gridlock requires improvements of the existing international framework. This is the triangle formed by the G20, the United Nations system and specialized international organizations. But for this approach to work, greater effort must be made to introduce the tools and benchmarks necessary to monitor organizational and institutional activities and to measure their successes, thereby improving their overall accountability.

In addition to this, there are also opportunities for advances in governance that are outside of the current global framework. For example, continued regional integration has led to different models of 'mini-global governance' in Europe. These, in their own way, are moving in the same direction in Asia, Africa and Central America. 


\section{The Impact of the Rise of China on the Current 'Legal Economic Order'}

There is fifth development leading to a questioning of the viability of the current global 'economic order'. This stems from the geoeconomic and geopolitical shift brought by China regaining the status of a major economic power.

It is obvious that some of the Chinese specificities are not in line with some of the underlying principles of the dominant global 'economic order'. This starts with the driving role of the state-owned sector in the economy. As already mentioned, following the fall of the Berlin Wall in 1989, there was a clear underlying assumption according to which the 'Washington Consensus' was to be the future point of convergence of economic and social systems in a globalized world. Events over the past 20 years have proven these assumptions erroneous.

Perhaps the biggest change is globalization's impact on the geopolitical landscape. This is uniquely exemplified in China's increasingly active presence on the global stage. Globalization has both enabled - and rewarded-a shift in production, investment and technology to emerging economies.

The result-as Martin Wolf wrote-is that the periphery is becoming the core and the core is becoming the periphery. ${ }^{4}$ The US remains a key player but it is no longer dominant. Fast-rising powers, like China, India, Indonesia and Brazil, play a role that was unimaginable even 20 years ago-while smaller developing countries want a say in a system in which they have a growing stake.

The simple-even simplistic-North-South divide has given way to a more complex world of many different Souths and many different Norths. Arguably, this multipolar system is much more 'democratic' than the previous 'economic order' which is manifested in the outmoded and redundant old post Second World War order. The days when a single or a few countries could design and direct the international system are gone. Yet the old powers are cautious to share the centre stage-and worried about decline-while the new powers are timid in sharing responsibility or designing a new, different 'order'.

China has the potential to play a real role in the formation of a new global order both political and economic. But the emphasis in the short term will be decidedly economic. The reason is that China has built strong economic credentials worldwide drawn from its track record in manufacturing and trade. On the political influence, and outside of China, the Chinese governance system engenders much caution and concern. The creation of a new world order is an opportunity that China should take very seriously and not squander. It will not mean China following the rules established by the US and Europe, but agreeing to a better level-playing field with them and others in order to keep benefiting from the benefits of globalization.

\footnotetext{
4"In the past few centuries, what was once the European and then American periphery became the core of the world economy. Now, the economies that became the periphery are re-emerging as the core. This is transforming the entire world." Martin Wolf, Financial Times, January 4, 2011.
} 


\section{A New Global Economic Order-Principles and Priorities}

A new global economic order must then be shaped in order to address the aforementioned limitations, and pitfalls of the existing one. This new order should be based on four principles, the recognition of which should bring about a number of changes:

The first principle should be the establishment of sustainability in three inseparable dimensions: economic, social and environmental as a collective goal. The first step in this direction would be to base these objectives on the United Nations Sustainable Development Goals as they currently exist.

The second principle would aim at rebalancing competition and cooperation. While market systems promote competition and produce efficiencies, the cost is a host of negative externalities imposed on both humans and nature that are becoming excessively stressed and must be corrected. Market systems could be reformed either by changes of relative prices, or by appropriate regulatory cooperation, or by new arrangements between capital and labour. The WTO would be one of the platforms for reaching this balance, but it is based on a triangle of the US, EU and China agreeing or disagreeing. This is not to say that the rest of the membership does not matter, but an agreement between the US, China and Europe is essential for any step forward in global competition, trade and investment.

The third principle has to do with changing preconceptions of convergence in economic and social systems. That means accepting coexistence as the new normal and recognizing that economic globalization and political globalization may not follow the same paths. Also, that a new global economic order should be compatible with different collective preferences, be they cognitive, cultural, religious or political as long as they recognize the dignity of each human person as enshrined in the UN Charter.

The fourth principle is about acknowledging that for international cooperation to deliver more global public goods, it cannot be left only in the hand of sovereigns and diplomats. Delivery of global public goods must be open to the participation and engagement of non-state entities, such as businesses, non-governmental organizations, big cities or even key academic and scientific research entities. Their proven ability to coalesce around impact-driven initiatives must be further put to the test if they are to contribute to these goals.

On the foundation of these principles, I believe that there are three priorities that the nations involved in the creation of this new world order should adhere to:

The first of these priorities is the reorganization of the above-mentioned coexistence, which will ensure a proper, level-playing field between different economic systems in order to ensure fair competition. This implies a reform of global rules based on a multilateral trading system. This is necessary in order to strengthen disciplines on state aid as well as a reform of the international monetary system in order to address the dominance of the dollar.

The second priority is to ensure that the new global economic order does better to deliver on global public goods such as the environment, health, social inclusion and 
security. This implies a transformation of the present model of capitalism. Examples of the transformation needed are a repricing of carbon in order to accelerate the decarbonization of economies or a standard for wages and collective social security that is higher than current levels. It also implies reforms of classical international organizations in order to strengthen global rules. This includes the WTO, which the US tried to weaken under Trump and the WHO, the limits of which were evidenced by the COVID-19 crisis. Then there are the IMF and the World Bank, which need to be rebalanced to address ingrained Western supremacy in these institutions. The same intention of refitting international cooperation and revitalizing multilateralism is behind the creation and the development of the Paris Peace Forum as a new collaborative global platform for state and non-state actors to deliver results more rapidly.

The final priority is to recognize that this new global economic order will also be a digital one as value creation migrates from tangible to intangible. This raises many new questions about how to ensure market transparency, competition as the value of data keeps growing with progress in artificial intelligence. This is a complex challenge as it aims to reconcile the benefits of openness of data flows on the one side and different precautionary systems for data localization, accessibility, security and privacy on the other. Such profound structural transformations of the dominant global economic order necessitate major adaptations of legal superstructures.

\section{Conclusion}

In this essay, a number of elements have been described indicating that the current global 'economic order', and the institutions that accompany, are not up to the task of delivering the necessary global public goods nor the benefits of cooperation.

While we cannot, and should not, revolutionize the system that is currently in place, we do need to consider how it should be reorganized and subsequently replaced by a new order. It is essential that the new order serves not only the established powers of the world but a greater number of the newly emerging economies and nations. The different principles and systems that they represent will be fundamental to this new order. The development of this new order must ensure that it is representative of a world that is markedly different from the post Second World War legacy. Those creating the new order are dealing with new challenges that could not even be imagined 70 years ago.

Humanity now inhabits a world that is more interconnected, more interdependent and in a word, more 'global'. This connectivity is part and parcel of the process of globalization which is not to be pushed back but better harnessed.

China and other emerging powers should embrace an ambition and strive to be greater contributors to shaping a new, more sustainable and fairer version of globalization: a new open and cooperative 'global economic order'. 
Pascal Lamy is the President of the Paris Peace Forum and coordinator of the Jacques Delors think tanks (Paris, Berlin, Brussels). He was the longest serving World Trade Organisation (WTO) Director-General so far (2005-2013). Between 1999 and 2004 he was the EU Trade Commissioner. He holds degrees from the Paris based École des Hautes Études Commerciales, the Institut d'Études Politiques and the École Nationale d'Administration. He began his career in the French civil service at the Inspection Générale des Finances and at the Treasury, then became an advisor to the Finance Minister Jacques Delors and subsequently to Prime Minister Pierre Mauroy. He served as Chief of Staff to EU President, Jacques Delors between 1984 and 1999.

Open Access This chapter is licensed under the terms of the Creative Commons AttributionNonCommercial-NoDerivatives 4.0 International License (http://creativecommons.org/licenses/bync-nd/4.0/), which permits any noncommercial use, sharing, distribution and reproduction in any medium or format, as long as you give appropriate credit to the original author(s) and the source, provide a link to the Creative Commons license and indicate if you modified the licensed material. You do not have permission under this license to share adapted material derived from this chapter or parts of it.

The images or other third party material in this chapter are included in the chapter's Creative Commons license, unless indicated otherwise in a credit line to the material. If material is not included in the chapter's Creative Commons license and your intended use is not permitted by statutory regulation or exceeds the permitted use, you will need to obtain permission directly from the copyright holder.

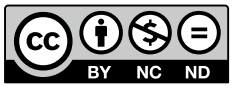

